\title{
THE INAUGURATION OF
}

\author{
WILLIAM MARION JARDINE, B. S., LL. D.
}

AS PRESIDENT OF THE

KANSAS STATE AGRICULTURAL COLLEGE 






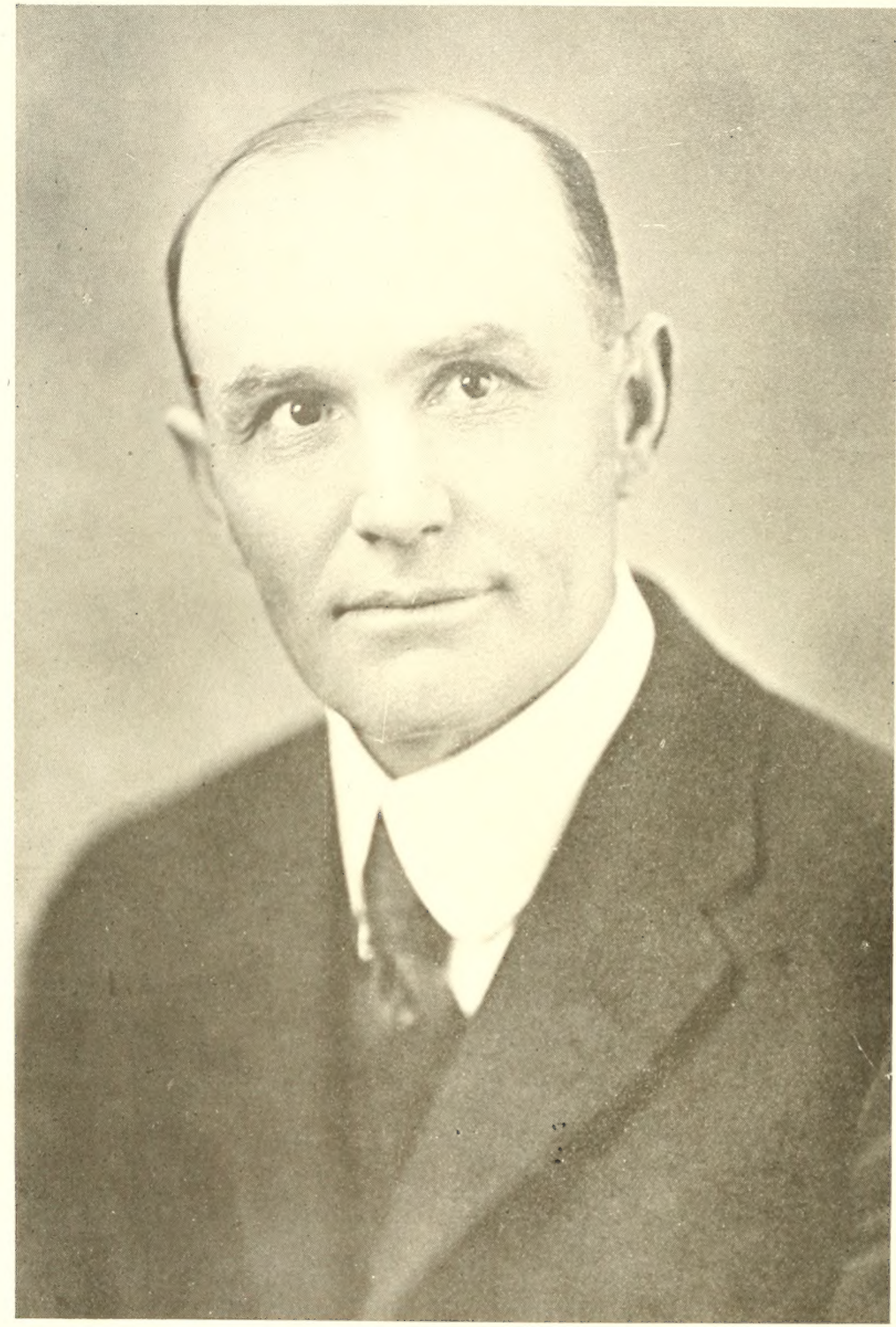

WILLIAM MARION JARDINE, B. S. A;, LL. D. 
THE INAUGURATION OF

\title{
WILLIAM MARION JARDINE, B. S., LL. D.,
}

\author{
AS PRESIDENT OF THE \\ KANSAS STATE AGRICULTURAL COLLEGE
}




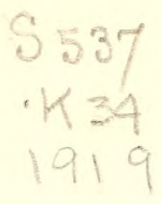

of Thanter

151919 


\section{THE INAUGURATION OF PRESIDENT JARDINE}

William Marion Jardine, Bachelor of Science in Agriculture, Doctor of Laws, was inaugurated as President of the Kansas State Agricultural College, at Manhattan, Kansas, on Tuesday, February 4, 1919, in the presence of officers of the State, representatives of other educational institutions, members of the faculty, alumni, students, and friends.

The ceremonies incident to the inauguration formed the chief feature of Farm and Home Week, the annual period in which the Kansas State Agricultural College is host to Kansas farmers and farm families.

The program of Inauguration Day was opened at 10 o'clock in the morning with exercises in the auditorium, the Honorable Edward Wallis Hoch, member of the Board of Administration and former Governor of Kansas, presiding.

The exercises began with Jewell's "Hail to Old Glory," played by the College Orchestra, during which the speakers and distinguished guests entered the auditorium. This was followed by Moszkowski's “Malaguana," played likewise by the College Orchestra, led by Professor Robert Henry Brown, '98.

Somervell's "High Over the Breakers" and "Music, When Soft Voices Die" were sung by the Music Faculty Quartet, consisting of Professor Arthur Edgar Westbrook, Miss Katherine Kimmel, Miss Bess Curry, and Mr. Clifford W. Johnston.

The Divine Blessing was invoked by the Reverend John Mark McClelland, Doctor of Divinity, Pastor of the First Methodist Church, Manhattan.

Mr. Hoch then introduced Raymond Allen Pearson, Bachelor of Science, Master of Science, Doctor of Agriculture, Doctor of Laws, President of the Iowa State College of Agriculture and Mechanic Arts, who spoke as follows: 


\section{ADDRESS BY DOCTOR PEARSON}

Mr. Chairman. Members of the Board and of the Faculty, Students, and all Friends of Education:

We have assembled to inaugurate your President who recently was elected by the Board of Administration to preside over the affairs of this college. Such an occasion marks a new epoch in the life of an institution. And when an institution is so important as this one has become, a speaker may well feel honored, as I do, by an invitation to have a place on the program.

It is my privilege to bring to you the cordial greeting and good wishes of Iowa State College. And although I have not received definite instructions from all other educational institutions, I feel sure I am safe in saying that they all would rejoice with you in the events of today and all would join in sincere good wishes for the further service and development of your college under the leadership of President Jardine.

$\mathrm{He}$ is fortunate in that he follows a man like Doctor H. J. Waters, who earned his enviable reputation as an agricultural leader and as an educator largely through his service as President of this institution. Doctor Waters, ably supported by Dean Jardine and other members of the faculty, and strongly backed by the educational authorities and citizens of the state, helped to establish in the minds of people everywhere, facts not only as to the standards and character of this institution but as to the greatness of Kansas.

Your new president is fortunate also in the fact that he is thoroughly familiar with the scope of the institution and its purposes, its personnel, and its history. Surely this is an auspicious beginning.

\section{THE SCOPE AND DEVELOPMENT OF LAND GRANT COLLEGES}

I want to say something about the service of such a college as this. Need I remind any one here that this college and one such institution in every other state are established and are rendering service in accordance with the provisions of a national law. The Act of Congress was passed during the dark days of the Civil War and is one of the most important pieces of legislation bearing the approval and signature of President Lincoln. It was the purpose of Senator Morrill, the author of the bill, and his colleagues in Congress to provide for the "liberal and practical education of industrial classes in the several pursuits and professions of life." They felt, and for 
.

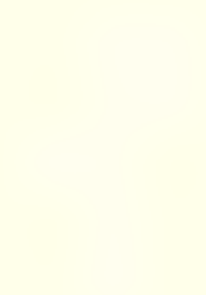

.

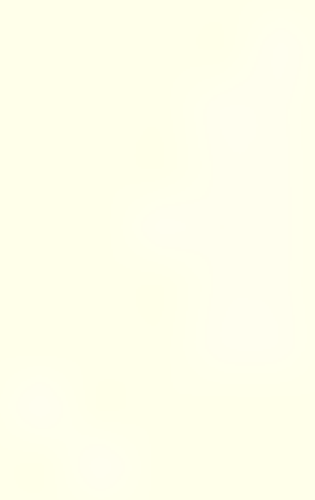




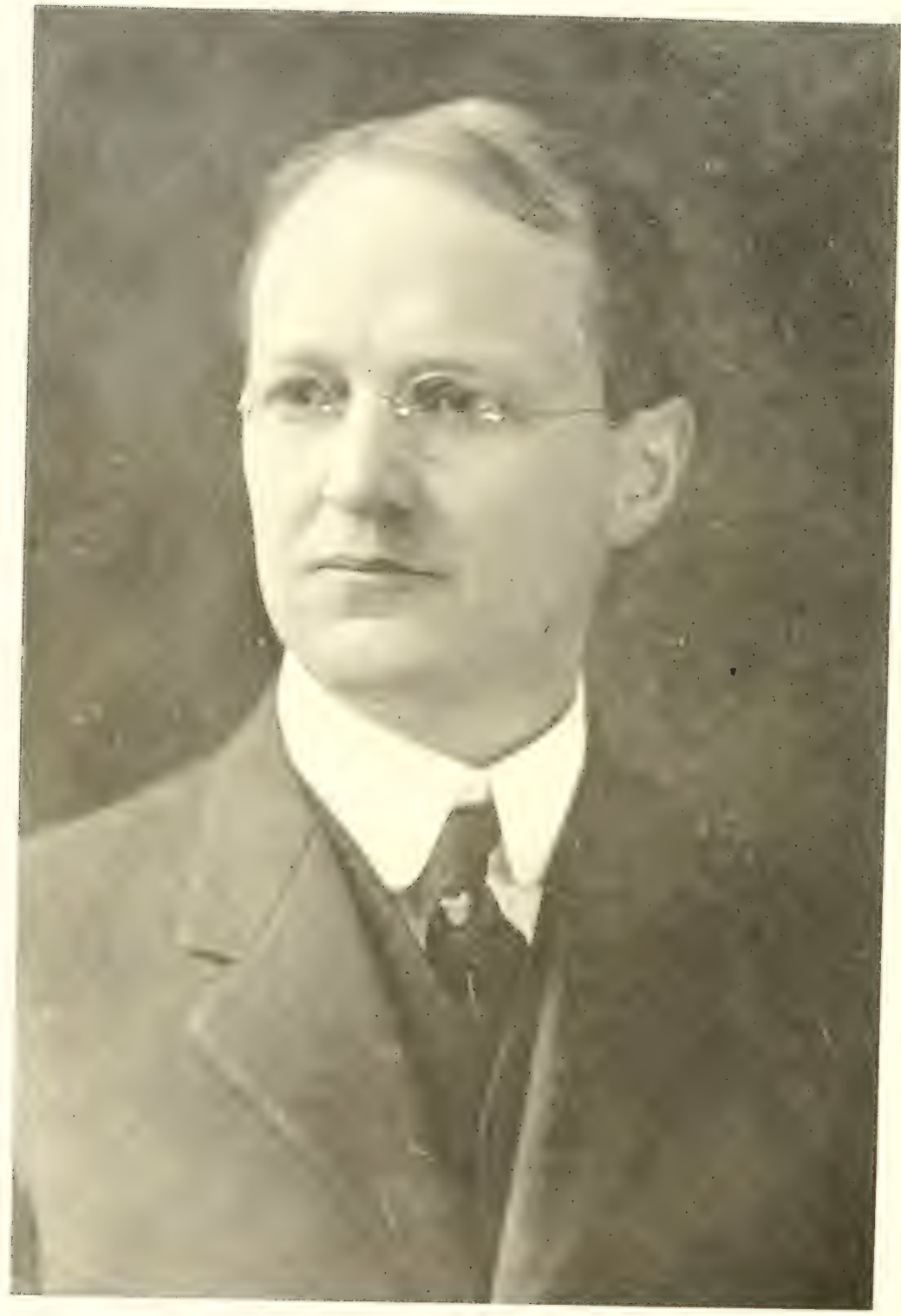

RAYMOND ALLEN PEARSON, B. S., M. S., D. Acr., LL. D. 
abundant good reason, that education along lines in which the masses were interested was being sadly neglected. The law requires that at such an institution the leading object shall be to teach subjects relating to agriculture and the mechanic arts. It is necessary also to include instruction in military tactics, and it is permissible to include other scientific and classical studies.

Before the Federal legislation could become effective in any state it was necessary that the Legislature of that state should formally accept the provisions of the national law. The Legislature of Kansas did this promptly in 1863. I need not take your time to review the history of this institution which is full of interest and which doubtless is known to you much better than to me.

The land grant institutions, one in each state, constitute a group of educational centers having the same chief purposes. They make the largest group of institutions of higher learning with common purposes, in all the world.

Some of the older people, including myself, well remember the difficulties encountered in putting agricultural instruction upon a collegiate basis and in making such instruction truly worth while, and then again in securing deserved recognition of this kind of work when well done. Three obstacles had to be overcome. First, opposition of many farmers who felt that they were not and could not be benefited by such institutions. There are some people inherently opposed to being told anything by anybody. In that respect I think some farmers are exactly like some other people who live in towns. Some of these farmers felt it was an acknowledgement of ignorance to be seen attending an agricultural institute or other educational meeting. Today one is more likely to meet a farmer who feels it is an evidence of ignorance not to be actively connected with and learning from some agricultural teaching agency.

But too often, in the early years, farmers holding the opinion that they could not be taught anything were in the right-not because they were incapable of learning more but because they already knew their business better than some of those who were asked to teach them.

The second obstacle was the difficulty in securing well trained teachers and investigators. The institutions doing the best work in those times were generally the ones which selected the most intelligent and successful farmers to have important places on their staffs, whether those farmers were college graduates or not. And that practice continues to the present day in the very 
best of our agricultural colleges. But now, thanks to the developments within the institutions themselves, there are many men engaged in the work who thoroughly understand practical farm operations and have the great benefit of sound training in the fundamental sciences.

And the third difficulty was the opposition of educators whose training had been along other lines and who failed utterly to appreciate that there might exist useful knowledge relating to such things as farming, and which was teachable in a college. They opposed introducing agriculture into the college curriculum and they belittled this work in countless ways. They were usually honest in their opposition.

It is amusing and sometimes pathetic to read of the struggles of the old "standpatters" in our institutions of learning who could not see educational values in soils or plants or animals. Occasionally a true prophet would appear. About eighty years ago President Francis Trayland of Brown University, a classical institution, succeeded against much opposition in placing certain scientific studies in his college curriculum. But a little later, support was witheld from this new work, and in 1855 President Wayland was forced to resign and the old classical work was re-established. He was a martyr to a true vision. $\mathrm{He}$ had studied the enrollment of New England colleges and the courses offered and he found small numbers of students attracted and he boldly stated that the colleges did not furnish the education desired by the people. He said, "We have in this country 120 colleges, 32 theological seminaries, and 47 law schools, and we have not a single institution designed to furnish the agriculturist, the manufacturer, the mechanic, or the merchant with the education that will prepare him for the profession to which his life is to be devoted."

One of the early educators who was opposed to agricultural education referred sarcastically to "the butter makers across the campus" who held their subject on a par with Greek as a part of the university education.

The educators were in good company. Some members of Congress agreed with them. In 1859, a Mr. Daris argued in Congress that the proposition to do something along educational lines for the agricultural interests of the country was delusive and fraudulent and that such interests needed no aid but were able to take care of themselves.

Wonderful changes have occurred. Congress has passed more laws, and the states have supplemented 
them, whereby the work of these institutions has been steadily enlarged and strengthened. Agricultural investigations have been developed on a large scale. They form the secure foundations on which the educational structure stands.

The Morrill Act provided in the same terms for both agriculture and the mechanic arts. In the law these two lines of work are equal and it is usual to give them equal opportunity in the land grant institutions. At some of these institutions, however, including this one, the name recognizes only one of these great subjects. At first there was predjuice against engineering education but that was easily overcome. Sometimes the question has been raised as to whether Congress intended land grant institutions to engage in real engineering educational work in view of the fact that the law uses the term "mechanic arts" instead of the term "engineering." There is no doubt as to the intention of the framers of the bill and of Congress in enacting the law. In those days the term "mechanic arts" included the whole field of engineering in its broadest sense as it is commonly recognized today under the term "engineering." In the early days the term "engineer" was used in a very restricted sense, meaning a man who ran an engine, or one who surveyed a road. Strictly speaking, "mechanic arts" represents the larger and broader field including not only engineering as we know that word but also other grades of work described as trade school work, or by other terms.

It is to be hoped that Congress will soon recognize the importance of completing the engineering equipment and rounding out the scope of this rork by establishing Federal engineering experiment stations in the land grant colleges, as was done years ago in the establishment of agricultural experiment stations.

A new line which has been developed at land grant colleges in full harmony with their original purpose and now directly recognized by Federal legislation is the work in home economics. Some years ago it was thought that engineering education had suddenly come into its own, as was evidenced by the rapid increase in numbers of students. A little later the same was remarked concerning agricultural education. Now we are witnessing a similar growth in the field of home economics education. It surpasses the other subjects in that it fouches literally every home in the land.

And much could be said about the development of veterinary education which has been brought to a high 
level of efficiency in certain colleges, founded on the Morrill Act.

Land grant colleges today are universally appreciated. What better proof that this institution is appreciated in the state of Kansas than the fact that your enrollment for this year includes nearly 2,500 students, a large increase over any previous year, and the fact that the tax payers have provided here substantial buildings for college use? Such buildings, costing a quarter to a half million dollars are now commonly found in the service of these colleges in different states.

And still better is the fact that the tax payers of Kansas are willing to supplement Federal funds to pay at least a goodly portion of your professors' and instructors' salaries that compare favorably with modest business incomes. The time was when a college could not get the strongest men because business interests would outbid the college authorities except in occasional cases where a teacher was so much in love with his work that he was willing to pay for the privilege of serving in this work. I said in occasional cases but I meant to say in many cases. The hardships of the underpaid professor were appreciated by the seven year old son of one of these professors. The little fellow was asked what he intended to do when he grew up. He replied, "Well, I hope I'll know enough so I won't have to be a professor."

While there has been improvement throughout the country in reference to salaries of teachers in all schools and colleges, there is need of more improvement. A teacher who has not sufficient income to keep his family in comfort and accumulate a very little year by year cannot do his best work. The public which fails to recognize this fact is the chief sufferer. It is very well to pay a janitor a good salary but it is a shame to pay a good teacher less than a janitor receives.

POINTS OF CONTACT BETWEEN LAND GRANT COLIAGISS

AND WAR ACIIVITIES

Let us review briefly some of the great events of the past two years and note a few points of contact between them and the land grant institutions, your own in particular.

Four million American men marched forth in well disciplined fighting units. More than 80,000 of them came from Kansas which already was short of men and short of labor. Have you counted how many of these men received more or less military training in this college, and do you know how much this meant to our nation in quick- 
ly leading to their elevation to commanding positions in the army and navy? It was at a time when our fate hung in the balance and capable military men were needed at once. I have seen your wonderful service flag and its glistening gold stars. They are proof of the patriotism of your students and graduates. I hope it will not seem immodest for me to tell you that 2,180 stars are on the service flag of the Iowa State College and forty-eight of these have turned to gold.

Strong appeals were made for an increase of food production. Our own consumption and consumption in the countries of the Allies were increasing by reason of the war. The Allies were producing less and they were prevented from getting their usual supplies from distant ports because the oceans were infested by submarines. It devolved upon this country and Canada to supply not only our usual quota but as much more as possible. The President of the United States, the Secretary of Agriculture, Governors, and army officials, all called for more food. There was danger of starvation in the countries of our Allies. It was known they could not fight if they were not well fed.

The relation of food to war is not sufficiently understood. At one time it was feared the food imports would be cut off from Great Britian and that this would quickly put her out of the fighting. In an Italian city flour was not available just one day and there were riots. I was told in France that at one critical time a shortage of coal threatened the transportation of munitions to the front. Investigation revealed the fact that the output of coal from the English mines had decreased because the miners did not get enough food.

A tremendous responsibility fell upon the American farmers. President Wilson recognized this fact. He recognized also that the farmers of America are patriotic people. He said on January 31, 1918, "The toil, the intelligence, the energy, the foresight, the self sacrifice, and devotion of the farmers of America, will, I believe, bring to a triumphant conclusion this great last war for the emancipation of men from the control of arbitrary government and the selfishness of class legislation and control, and then, when the end has come, we may look each other in the face, and be glad that we are Americans and have had the privilege to play such a part."

A PROPER RECOGNITION OF THE AMERICAN FARMER

Who did win the war! There is a hint in the President's words as to who did. But I don't believe all the 
credit belongs to any one country, group, or person. Labor makes its claims. The railroads make theirs, so do the packers, and now we are told that the automobile industry claims that they contributed more toward winning the war than any other peace industry of the country except steel. In our talk about who did it let us not forget that France laid down one million lives and Great Britian nearly one million. Let us not forget the British fleet nor the British women and their heroic service. But coming back to our own country I think we can easily agree that our war efforts may be compared with a threelegged stool - they would have collapsed if either leg had failed. One leg was our splendid army and navy. Another was our rast industries and transportation. And the third was our agriculture.

Though the best workers were leaving our farms by the hundreds of thousands. those who remained behind exerted themselves to the utmost and produced such a quantity of food crops as this country had nerer seen-in 1917, nearly a billion bushels of cereals more than the five year arerage before the war started in Europe. And almost as large a production in 1918. And in each of these years there were more horses, mules, milch cows and other cattle, and many more swine than before the war. There was a slight decrease in numbers of sheep. The estimated production of beef, pork and mutton in 1918 exceeded the production in 1914 by about four billion pounds, or about 25 per cent. In 1918, the acreage of the principal cereals in the United States exceeded the normal acreage before the war by nearly 40 million acres, or nearly 20 per cent.

In 1918, we exported enormous quantities of food to the Allies. Increases over the normal pre-war exports were for corn (and meal) 101 per cent, wheat (and flour) 126 per cent, oats 1296 per cent, barley 334 per cent, rye (and flour) 1929 per cent, rice 623 per cent, beef and its products 271 per cent, pork and its products 185 per cent, condensed milk 3358 per cent, cheese 1804 per cent and mules (not for our own army) 1127 per cent. Of course our surplus had been decreasing in the years before the war, but these figures speak volumes.

In announcing these stupendous figures, the Secretary of Agriculture gives great credit to the farmers of the country and especially he mentions the colleges of agriculture, which, with the Federal Department of Agriculture, were leaders in making plans, securing necessary additional equipment and supplies, in combating pests, in finding additional labor and in helping to save and to 
market the crops. I may say some of the most prominent government officials who were in close touch with all war efforts of all kinds, frankly have stated that the agricultural institutions were the best organized and responded the quickest of all agencies in our country when the war demands were first felt.

The state of Kansas takes a very prominent position in the list of states in this connection. On the basis of the wheat crop she stands at the head of the list. Your annual average production during the five year war period exceeded 100 million bushels. In only one previous year, when all conditions were especially favorable, did your state turn out such an enormous crop of wheat. No other state could make such a showing. It is estimated that you now have nearly 11 million acres in wheat. The values of your principal crops during the five year war period are almost beyond our ability to appreciate. For the present year, we are told by Secretary Mohler that the values of farm crops and products, including slaughtered animals, approximates 600 million dollars. In some parts of the state the newspapers could render a splendid service by giving greater prominence to such facts as these and less to murders and scandals.

Dean Johnson and his many associates, paid and unpaid, could write volumes on what Kansas did in the way of speeding up production. And doubtless Dean Van Zile and her assistants could write more volumes in describing what was done especially by the women of Kansas in saving and substituting in the home, to say nothing of working at men's jobs. If they could be secured, the figures showing what has been saved in Kansas, especially in the homes, under the leadership of experts in home economics, would be profoundly interesting.

The story of your service along engineering lines also is highly creditable. I fear we sometimes make the mistake of thinking that engineering work is not a work of importance in these agricultural states. Your great flour mills and packing houses were speeded up. Your mineral interests were called upon for greater efforts. Your railroads and highways had to be kept in repair. The public service facilities, including water supply and sewage, all had to be safeguarded and at places enlarged. I am informed that your Engineering Division assisted municipalities and industrial plants to overcome many problems which were especially difficult on account of war conditions. In addition to this, special engineering training was given to many hundreds of young men preparing for 
service in the army or in the industries that would contribute to our military strength.

The experts of this college were busily engaged in Kansas but they were called upon also to serve in larger fields. President Waters became a member of the fair wheat-price committee. I am satisfied that the price agreed upon for wheat was more fair than it would have been if he had not served on that committee. Dean Jardine was called upon to give expert advice concerning seed wheat and other important questions relating to other states as well as to Kansas. Later, as your President, he came to Washington especially to spreed up arrangements for getting temporary help into Kansas to care for the harvest. He was tremendously in earnest when on this mission and I doubt not that through his efforts enough additional wheat was produced in Kansas in 1918 to bring into your state an enormous sum of money. But to the nation the most important thing was to get the wheat. I well remember the spccial service of Professor Fitz in a conference of agricultural leaders from twelve states who met in Kansas City to decide how far the farmers should be urged to go in producing additional crops. Dean Potter was called to a service of great importance in connection with the training of mechanics for the army. Many thousands of men were trained under his direction. We in Iowa were glad to have him in charge of our district.

The more one learns of the service of the land grant institutions during the war period the more he feels that it was an inspired thought in connection with national defense that led to the enactment of the Morrill law during the period of the Civil War.

\section{LAND GRANT COLLEGES AND RECONSTRLCTION PROBLEMS}

We are now entering upon a period of reconstruction and the relation of the land grant institution to the new problems becomes a question of vital importance. Reconstruction problems effect primarily the great industries of the country. The farmers, the railroads, the manufacturers, the laborers, and the home makers are the groups chiefly concerned in reconstruction problems as these are being argued in the halls of Congress, in the cditorial columns, and at all places where intelligent men

\section{ACTIVITIES}

The farmers' relation to reconstruction is the most important of all. It must be remembered that in this country there are more farmers than any other class. When 
their business is doing well, business everywhere is good, Everything possible should be done now to make agriculture attractive to those who are engaged in it and to others who really ought to return to it. Amang other things, this means, of course, the maintenance of fair prices for agricultural products. If farmers have reason to think that they are not treated fairly great numbers of them will leave the farms and go to towns and cities and profoundly affect the labor situation by increasing the number of unemployed. When we remember how universal is farming and how many are engaged in the business we appreciate what it would mean to this country to have even a small portion of them decide to change their work from the country to the town. On the other hand, if farmers are satisfied, there will be a tendency to draw the better class of agricultural labor from the town to the country and thus tremendously relieve a trying situation.

Without doubt the government will maintain the price of wheat for the 1919 crop in accordance with the guarantee which was made by the President under authorization by Congress. Already there have been some sharp questions asked by editors of metropolitan papers as to why the wheat price should be maintained since the armistice has been signed. There are two good reasons. First, because Uncle Sam promised it would be maintained and Uncle Sam will keep his word. Second, because there is not such an enormous quantity of wheat in the world as to indicate that this essential food will go begging for a market in the near future. Official figures recently issued from Washington show that the import requirements of wheat for all Europe in the year 1919 will probably amount to 728 million bushels and the quanity available for export from Canada, Argentina and Australia will amount to about 495 million bushels, leaving a deficit of 233 million bushels of wheat in 1919 without regard to the crop in the United States. In this country we will have a surplus from the 1918 harvest of 277 million bushels. This is sufficient to make up the world deficit and leave a surplus of only 44 million bushels. Needless to say, that is a very small surplus. A short period of unusual weather may easily result in increasing or decreasing the crop in this country by very much more than 44 million bushels, to say nothing of the possible effects of bad weather on the wheat crops of other countries.

The wheat price problem and every other problem relating to the cost of food production and market prices vitally affects the farmers and they look to their agricultural institutions for reliable information. I think some 
colleges have felt a hesitancy in the past in connection with the development of their work along the lines of agricultural economics but now the farmers themselves are asking for this. Yes, demanding it. A few days ago one of the strongest agricultural organizations in the country adopted a resolution formally asking agricultural colleges to give more attention to subjects relating to cost of production and marketing.

New problems are presented by schemes for colonization of soldiers and other schemes to furnish ready made farms. Some of these schemes are based on the false idea that a farmer can be made in a minute.

The labor question is another great reconstruction problem. Already we are being warned that there is more labor in some large industrial centers of this country than is needed. Here is an appeal to agriculture and to every other great activity. Unemplovment leads to distress and may lead to violence. Our national government has recognized the situation by ordering certain large items of construction to proceed at once. States are asked to take similar steps. In my own state a strong feeling exists that the erection of permanent college buildings should proceed as soon as possible and that liberal funds for this purpose should be made available immediately so that the money may be used by the responsible board whenever in their judgment it is opportune and right to build. Under this necessity the Iowa State College may secure a much needed library building and at least one or two other important structures.

The readjustment of manufacturing whereby peace products will be turned out in place of war products is an item of great importance. The usual materials of construction are still high in price. A great service may be rendered by any institution which can show how substitute materials of construction may be utilized to advantage. For example, in this western country we might learn to use more of clay products and more of cement mroducts and depend less on steel and iron. The transformation is coming. It ought to come more rapidly. There will be a time when our building products in this section, as food products, will come from our own territory in very large if not in full measure.

Fuels are expensive and hard to get at any price. Some day we shall use the greatest power on earth, the wind. When we hear it whistling around the corner of the house we ought to feel that it is laughing at us because we have not found a way to avail ourselves of its great strength. One who has studied the subject is re- 
sponsible for the statement that in the course of a year sufficient wind power passes through a few square rods to furnish all the light, heat and power needed on an average farm, if it could but be wholly controlled. This is a question for the future. Questions of more immediate promise relate to methods of making more efficient use of the fuels we are now consuming.

These are only a few samples of the very many reconstruction problems. Then too, we have many of our old problems coming back again in new form and more important than ever, - such as farm tenancy, conservation of soil fertility, keeping up food production, combating countless pests and diseases, conservation of natural resources and the ownership of public utilities. It seems that almost every one is connected with such a college as this, and those in charge well may be impressed by the great responsibility that falls upon them in these new ways.

There is to be reconstruction also in connection with the courses of study offered in our colleges. Educators themselves, as well as others, must reconstruct their work wherever new conditions demand. You must remain alert lest you be led astray by false signs and make changes that should not be made and equally alert lest you adhere to what is no longer appropriate. For many years these reconstruction problems will be the most difficult with which you have to contend. The Board of Administration, the President, and the Faculty will be urged to do this and that, and they will be criticized for not acting more quickly. God grant that they shall have the wisdom and backbone and strength to do what is right.

One of these new problems pressing for immediate solution is the development of military work in the college under the new conditions and changing regulations. Of course military work will be continued but it should be made of higher educational value than in the past, and more emphasis should be given to the physical training side of the work. The new army now being planned in Congress will need very many men well trained along: technical lines and in military tactics.

It would be interesting to discuss more intimately some of the problems with which faculties are now wrestling, the questions of maintaining educational standards, receiring the boys back in college at any time they are released from the army, substituting credits of one kind for others considered of equal value, readapting courses of 
study to give better training for the new demands that are arising, and countless others.

Too often teachers have the fact impressed upon them that in occasional cases a serious mistake has been made, and perhaps there has been actual injustice, by providing education to an individual who was not qualified physically to make use of what he learned or morally to make the proper use of his knowledge. It must not be overlooked that young people developing into manhood and womanhood need something besides education. They need good health and they need good character. To what extent an institution should go in providing these needs may be an open question. But there is no doubt that a responsibility in this connection rests upon every college president and professor. The student who goes forth from an institution with his health wrecked is relatively a poor investment for the state. My thought is well expressed by Bacon, who said many years ago:

"If by gaining knowledge we destroy our health, We labor for a thing that will be useless in our hands; He that sinks his vessel by over lading it, though it be With gold, and silver and precious stones, will give its Owner but an ill account of his voyage."

In respect to physical training the colleges are making progress but not as much as they should. At some institutions the faculty, and particularly the physical training staff, have the good sense and the courage to prevent the so-called big games from dominating the whole athletic situation. Athletics for the many, rather than for the few, should always be the leading aim. Instead of one baseball nine there should be twenty or thirty.

When a state furnishes an education to a young man or a young woman at considerable cost, it expects that person to become a better and a more useful citizen by reason of the education. One's character is developing as he receives his education. The great question is whether the character is improving. Through more careful training of character in many a case the elucation would be doubled in its ralue to the state. Without doubt the mistake has been made of investing money in the education of a person whose character was so low that the education was used for destructive rather than constructive purposes. We do not put weapons into the hands of wild men who may turn them against the things that are good and useful. The world now sees this happening in Russia. For just as good reason we should not train the minds of persons who do not know how to use or 
who will not use the training for the benefit of the state which gives it to them. It is not always easy to detect such persons but when they are discovered they should be eliminated from an educational institution. Such measures strictly imposed, together with proper steps to help develop character in right minded young people, are problems which college faculties have to wrestle with and are solving with more or less success.

There is then a threefold obligation to be performed for the student, - to provide educational, physical, and moral training. It is gratifying to know that the majority of students, themselves coming from good homes, appreciate the threefold need as well as their instructors appreciate it and are glad to cooperate in making the efforts along all these lines effective.

\section{SUMMARY}

Mr. Chairman, I have not tried to cover the whole field of higher education. One is tempted at a time like this at least to refer to the special problems in other institutions, particularly those which are being handled so well by your sister institution,- - the State University. These would carry us into the fields of law, medicine, dentistry, pharmacy, architecture, commerce, and various branches of the liberal arts. But I have mentioned some important problems that are common to all colleges and universities and which may be called citizenship problems.

May I summarize by saying that this institution, under the requirements of its charter, must give special attention to agriculture, the industries, and to military training. The work must be of three kinds, - teaching on the campus, research, and extension. Because of the large number of people interested in these lines of effort your work is bound to proceed on a large scale and, if well done, it will affect the welfare of every part of the state, directly or indirectly.

It is a privilege to be a member of the faculty of such a college in normal times, and, for a man or woman of ability, integrity and unflinching courage, it is thrice a privilege now as we enter upon what may prove to be the most difficult period in our history, because of the great problems which must be faced and solved.

We shall come through this period as victors, with the aid of some bulwarks against unreasonableness and unfairness and unrighteousness, which this nation possesses. And one of the chief of these is our educational system. 
President Jardine, on this day of your inauguration, I come to congratulate you as the chief executive officer of this great college. I believe that all people here and elsewhere who know you and know of your splendid qualifications, would join me in an expression of confidence in you and in the wish that you will enjoy a long period of service, and that in this service you will constantly find your chief compensation in the success and happiness that come to you together with the consciousness that your work is being faithfully done.

At noon a luncheon was served by the Department of Domestic Science to the speakers and other invited guests.

The afternoon session was opened at 2 o'clock with Fillmore's "His Excellency" and Elgar's "Pomp and Circumstance," played by the College Orchestra.

The Invocation was pronounced by the Reverend Drury Hill Fisher, Bachelor of Arts, Master of Arts, Doctor of Divinity, Pastor of the First Presbyterian Church, Manhattan.

The II Verdi's "Rigoletto."

President Jardine was then formally inaugurated into office by Mr. Hoch, representing the Board of Administration. Mr. Hoch spoke as follows:

ADDRESS BY MR. HOCH

Members of the Faculty and Student Body of the Kansas State Agricultural College, and Friends:

If one should ask this fine audience, 'What is the greatest event recorded in Kansas history?' there would doubtless be a great variety of answers. Some, undoubtedly, would answer, "The Admission of the State into the Union." While that, of course, was an important event in the history of the state, it was an inevitable event involving only a question of time.

Others, no doubt, would say, "The adoption of the Prohibitory Amendment to the Constitution is the most important event recorded in Kansas history," and its importance, indeed, can scarcely be overestimated, for in 
the light of recent events, "Behold how a little leaven hath leavened the whole lump!"

Still others, one may easily believe, would contend that the enfranchisement of women is a sufficient answer to the question, and who can overestimate the importance of this just act of the people of Kansas-the taking into governmental partnership the other and better half of our population? Some might even insist that the adoption of the Bone Dry Law measures up to a satisfactory answer to the question. Numerous other answers could be and doubtless would be made by partisans of various different State interests, which have passed into history; but you will pardon me if I give you an answer quite different from all of these while acknowledging gladly the importance of them all.

At a time when the State had only a little more than 100,000 population and most of them exceedingly poor, as pioneers proverbially are; at a time when the Nation was involved in the Civil War, and the war clouds hung thick and black over this new state; when the tramp of invading armies was heard upon our streets and the blood of our citizens was being freely shed for the protection of their homes; when the fate of the Nation and of the State hung in the balance-in the very midst of those awful times the voice of the Kansas Legislature was heard above the din of battle and the cries of distress proclaiming the establishment of the three great parent educational institutions now flourishing in the state: The University at Lawrence, the Agricultural College at Manhattan and the Normal School at Emporia. This educational vision voiced in the statute of '63, this laying of the cornerstone of our whole state educational system under those extraordinary and trying circumstances, is, in my judgment, the greatest event recorded in Kansas history.

We have met today formally to induct into office the seventh president of one of these great institutions of learning. May I impart to you a secret concerning his selection for this important position? Our entire Board went to Washington in January, 1918, to find, if we might, a successor to Dr. Henry J. Waters, who, for ten years, had been the distinguished President of this institution, but had recently resigned. We spent three days in attendance upon what is said to have been the greatest gathering of agricultural college presidents and professors and other college celebrities ever assembled in the United States. We interviewed numerous distinguished educators, including the Secretary of Agricul- 
ture, himself an old college president; the Commissioner of Education; and many other prominent people equipped with knowledge valuable to us. We listened to nearly all the discussions and studied personalities from every possible angle and, without reflection upon any of the eminent gentlemen we thought eligible for the place, we finally decided that, taking everything into consideration, it was not at all necessary to go outside the State of Kansas to find a worthy successor to Doctor Waters; and in this way, and for these reasons, his mantle has fallen upon your new President, Dr. William Marion Jardine, so long and so successfully connected with this institution. His fame is not confined to Kansas, and, indeed, his selection was urged upon us by many of the most distinguished educators we met in Washington.

And now, without unnecessary formality, in behalf of the Board of Administration and in behalf of the state we officially represent, I have the honor and pleasure of introducing to you your new President, Dr. William Marion Jardine.

Thereupon Doctor Jardine formally accepted the office of President of the Kansas State Agricultural College, and delivered his inaugural address, as follows: 


\section{ADDRESS BY DOCTOR JARDINE}

\section{Mr. Chairman, Guests of the College, Members of the Fac-} ulty, Students, Friends:

With a deep sense of the honor conferred upon me and the responsibilities involved, I accept from you the office of President of the Kansas State Agricultural College. I pledge myself to maintain that which is best in the institution's past and to strive to direct its future along right paths. To the governing board, the faculty, the alumni, student body, and friends of the institution, I must look for that loyal cooperation and assistance which alone can make my efforts successful.

While this occasion is unique in my own life $I$ feel that it differs from many similar ceremonies in one particular, namely, in the fact that I have already been associated for a number of years with the college of which I am to become President. These years have afforded unexcelled opportunities to learn the aims and ideals of the Kansas State Agricultural College and to discern its animating spirit and purpose. I am now brought to the point where the unusual opportunities afforded in preparation for a work unforseen are transformed into immensely increased responsibilities.

It is with the humility of the sincere probationer at the beginning of his period of trial that I am here. Only the years can determine the wisdom of the choice which the governing body has made. The task I now assume is to interpret correctly the history of the college. to apprehend wherein lies the force it now exerts as an educational and social power, and in the light of the immense changes which are taking place in the world about, to perceive the present and future mission of the institution and to formulate the lines along which its future progress must be made.

The Kansas State Agricultural College, it must be constantly remembered, is not simply an educational institution instructing a relatively small body of selected men and women on a campus at Manhattan; it is also a great and responsible instrumentality for enlarging the agricultural and industrial life of the state. In the natural course of development, each of the state institutions of higher learning has corne to fill a particular need. Each is essential to the upbuilding of the state. Each must be free to develop in its own clear-cut field and in that field its stress should be laid. Not a little of the credit for the present happy relations of the state educational institu- 
tions is due to the high type of Kansas citizens who have formed the governing boards. Progressive, broad-minded, fair, their efforts have resulted in the working out of a definite plan of action for each institution and in making the state's progress and welfare the guiding and inspiring principle of all. The service which the Kansas State Agricultural College is rendering in its leadership in public movements, in pointing the way to more efficient agricultural production and distribution, in working out more effective industrial methods, in teaching efficiency in home administration and encouraging higher standards of home life. in dereloping higher ideals of citizenship and service, was brought to fruition during the administration of Doctor Waters, whom it was my pleasure and good fortune to work with and to serve through so many years. It must be the continued mission of the institution to serve in and to enlarge these fields.

In the realm of the college proper, it shall be the aim of our teaching in the future, as in the past, to give training of the highest professional type in the fundamental sciences and liberalizing subjects, as well as thorough training in the several technical curricula. Emphasis will be placed also on the practical viewpoint. We want students to know the problems that are to be solved and to be able to meet men and women of the work-a-day world on a common ground of understanding. In a larger way the aim of our teaching and training will be to produce not only the practical agriculturist. engineer and housekeeper, but also young men and women trained for leadership, young men and women who have been led, through a study of the social relations combined with professional and practical training, to have a larger vision of the duty of college trained men and women as leaders in community development.

The institution will also continue to make adenuate provision for those desiring practical training briefer than that given in the regular curricula. Those whose opportunities for preparation have been limited will find in the Kansas State Agricultural College, courses designed to meet their needs. The short courses now offered to the busy farm boy, to the girl who can be spared for but a few months from the home, and to the shop man who can come only for a few months during the slack time in his occupation, will be increased and expanded. It will be many years before the practical working out of the provisions of the Smith-Hughes Act will eliminate the need of such training on the part of agricultural and mechanical colleges. The scarcity of trained workmen 
which the needs of the war brought so vividly to the minds of the American public, demands that state institutions endeavor to prepare that portion of the state's citizenship as they never attempted to prepare them before.

The participation of the United States in the Great War brought to the Kansas State Agricultural College, as to other educational institutions, new opportunities to show its adaptability to public needs. While it curtailed slightly the quantity of teaching and investigation on the campus, it increased many fold the institution's service in the state. The boundaries of the College campus have become, in truth, the boundaries of the state. While in the future, as in the past, the institution will owe to the state professional and practical education of the highest quality for Kansas young people, the steady trend of the institution's development during recent years, accelerated by the events of the past eighteen months, would seem to indicate that in extention teaching lies one of the major means through which it will be able to inspire an improved and enlightened agricultural and industrial life within the state. It shall be the policy of the institution to inspire leadership among the people, to bring forward the potential leaders of the rural communities.

The work of the agricultural experiment station must be maintained on the same high plane as in the past. The results of experiment station research and investigation, together with assembled facts as worked out by practical farmers, form the basis and foundation of all college teaching in agriculture and all agricultural extension work. Three years ago, the recognition of agriculture as an organized science was observed in the formation of Section M of the American Association for the Advancement of Science. This was a significant event in the history of agricultural colleges and experiment stations. It forms, however, only the first definite milestone in the evolution of agricultural science. Only the simpler problems of agricultural industry have been solved. Longer periods of preparation and more intensive training will be required of those who would solve the more difficult problems remaining.

Agricultural research progresses quietly. Its operations carry little popular appeal, nor is premature publicity to be desired. Agricultural research and investigation, however, are dependent upon public support. It is the responsibility of those who are the guardians of agricultural science and those who have cause to appreciate its fundamental value, to see that the latest comer 
among the organized sciences is not curtailed or hampered for lack of funds.

Engineering research is a field of scientific investigation which is destined to grow and to play a large part in the improvement of agricultural life. No adequate financial support, either from state or from federal funds, has as yet been forthcoming for this work. Valuable work is being done with the means and the force available and this will be continued and increased to the greatest extent possible. Engineering experiment stations should be created through proper congressional action, and federal funds added to state funds for the furtherance of engineering research. With federal recognition and adequate financial support, engineering investigations will quickly demonstrate their economic value.

If the Kansas State Agricultural College is to continue its leadership in vocational education, it is necessary that the men and women composing its faculty and staff keep in mind the peculiar purposes underlying its foundation. They must discriminate between the functions of colleges of liberal arts and the social and industrial problems, to cope with which, this institution was created. A common criticism of college faculties is that they are unpractical, that they do not keep in touch with the work of the world. An institution such as this should have as a primary purpose the undertaking of such work as will keep its faculty in close touch with the practical work of the world. They should be ready to meet the leaders and directors of professions and industries alike, on a basis of ecpuality and efficiency, so that they may have the respect and confidence not alone of their academic associates, but of the men who are doing things in the work-a-day world.

The need for acquiring and maintaining the practical viewpoint does not lessen the necessity for the maintenance of scholarship in the faculty. Every faculty member should be an authority in his subject or should be in process of becoming such. Advanced study and research and the policy of granting leaves of absence for this purpose, will be encouraged in the future, as in the past. In addition to a practical viewpoint and scholarship, loyalty and faithful, conscientious effort are necessary on the part of every individual comprising the faculty. The workers of the Kansas State Agricultural College have embodied these characteristics to a marked extent, and therein lies a secret of the growth of the institution. If each individual continues to do his part, no fears need be entertained for the future success of the institution. 
In the matter of the relations of faculty and students I hope to see great improvements effected. The influence which the teacher may exert in the life of the student is not limited to the class room. Where teacher and student meet as individuals outside the class room, great mutual benefit may be gained. The student may receive from the teacher of broad view and generous sympathy the greatest impulse and inspiration to do and to become; from the student the teacher may gain a fresh viewpoint and through him come to know the community whose life the student reflects. In an institution of large numbers it becomes more and more difficult to preserve personal contact between faculty and student body, yet I believe that this is not impossible ; I believe that it has not always been preserved because insufficient effort has been made to this end. I believe that the social center is as desirable and necessary for the best life of the college community as it is for the rural or the urban community. I hope to see developed on the campus of Kansas State Agricultural College such a center, in which students and college workers may mingle freely. The land grant institution affords an appropriate field for working out such a project.

In the matter of the relation of the institution to the people of the state, it must meet the responsibility of leadership which it is expected to assume. It must have such a vision of the future that it anticipates new problems and prepares for them. It should not be ultraconservative, it should not become static, but should be essentially dynamic and progressive. Rather than hinder progress, it must point the way to new and greater achievements. In working out this larger purpose, as well as in the performance of its time-honored functions, the Kansas State Agricultural College should find in its alumni a great source of inspiration, encouragement, and support. An effort should be made to instill fresh interest in the Altimni Association of the Kansas State Agricultural College and to awaken in all those who go out from the institution a sense of personal responsibility for the future of their Alma Mater. Only through a strong association of loyal, patriotic alumni will a real college tradition develop and live.

The people of the state have taxed themselves freely that higher education might be available to the young people of the commonwealth. Those of its young men and women who are privileged by circumstance to enjoy directly the fruits of the state's beneficence, form, however, only a small part of the whole of its citizenship. 
Their responsibilities and the debt they owe to the state are increased in direct relation of their numbers to the whole. They should study the state's needs, endeavor to anticipate the problems that will confront its people in the years to come, and strive to discern what present action is needed to insure their proper solution. Through constructive criticism and suggestion the alumni have power to influence and help mold the line of action of their Alma Nater. Friendly co-operation and the combining of all forces are needed for the advancement of the state, industrially, economically, and socially.

The present and future mission of the Kansas State Agricultural College then would seem to be fundamentally the continuance of its leadership as a land grant institution in the further development of agricultural science and the mechanic arts, in the training of young men and women as leaders, teachers, and technical workers, and in the dissemination of adranced information throughout the state in promoting higher standards of agriculture, industry, and community life.

"No man liveth to himself," however, is as true of institutions as of men. The period of world readjustment toward which we looked during the years of war is upon us. In this readjustment period, education must take a leading place. and all educational institutions must cooperate in making the contribution of education one which will raise the race of men to new standards of efficiency, justice, and welfare. To this great cause Kansas State Agricultural college must make its contribution of talent, thought, and labor. As the enlightened, capable individual, having achieved success in his own life, finds his greatest opportunity for growth in serving society, so will the Funsas tate Agricultural College find, not in selfseeking and personal aggrandizement, but in a desire to serve where service is needed and a willingness to join hands with all other agencies in advaneing the common welfare, its highest opportunity for growth and a true basis for claim to greatness.

There are many signs of a new virility in education. In England Parliment has passed an Edueation Bill which is a distinct forward step in providing a greater degree of education for the youth of that country. England, inclined in the past to be ultraconservative in her educational policy and to cling to the formal type of academic training, has made wonderful strides in educational reform since 1914. Many English authorities, however, are still unawalie to the extent of the reforms which are needed in the English system of education. The British 
Labor Party approaches more nearly to a proper comprehension of the duty of the government in education. It has inserted in its platform a plank which reads: "The conference holds that the most important of all the measures of social reconstruction must be a genuine nationalization of education, which shall get rid of all class distinctions and privileges, and bring effectively within the reach, not only of every boy and girl, but also of every adult citizen, all the training, physical, mental and moral, literary, technical and artistic, of which he is capable." The Labor Party points out that while appreciating the advances indicated by the proposals of the present Minister of Elucation, it cannot be satisfied with a system which condemns the great bulk of the children to merely elementary schooling-which. notwithstanding what is yet done by way of scholarships for exceptional geniuses, still reserves the endowed secondary schools and even more the universities, for the most part, to the sons and daughters of a small privileged class, while contemplating nothing better than eight weeks a year continuation schooling up to the age of eighteen for 90 percent of the youth of the nation.

In the United States popular education has always been far more advanced than in Fngland. The founders of the American colonies were keenly interested in national education and believed that only a well-informed and well educated nation could be happy, prosperous, and free. The fathers of the Republic made ample provision from the outset for general elementary education and for education in the professions. No provision was made for industrial education, however, because at that period industry was centered largely in the home. That part of the industrial knowledge and practice which could not be transmitted personally from parents to children could be supplemented satisfactorily through the apprenticeship system in vogue.

The original provisions for general education were in time supplemented by free public secondary schools and there was then an open and continuous pathway from the elementary school to the university. The develomment of this comprehensive system of general education in this country has been of inestimable value in the growth of our free institutions and the development of a homogencous people. On the other hand, its shortcomings and defects have been many and obvious. If a young man wished to enter one of the older professions, ample opportunities were at hand, but there was no university or college training to provide leaders for the industrial army. 
The schools afforded little if any useful, practical knowledge to those engaged in agriculture, engineering, and manufacture.

To meet the growing need for practical education there was enacted the Land Grant Act of 1862 which laid the foundation of a national program in vocational education, an innovation which was considered by many to be more or less dangerous, but which has demonstrated the practicability of learning by doing. The more than ten thousand men and women who constitute the professors, instructors, extension workers, and experiment station investigators of the land grant institutions today, and the more than 130.000 students enrolled therein, testify to the wislom of the act and the breadth of rision and public spirit of those who made it an actuality. The land grant institutions have experienced an incredibly rapid development in number of students, in faculty, in yearly income and value of demonstration farms, and in the value of all property. Their growth, while rapid, has, however, been through the natural means of experimentation and study and the mapping of the course in new fields has not been without error. The land grant institutions with their inseparable coadjutors, the experiment stations, now occupy a position of far-reaching power and influence in connection with the most vital interests of the state in which they are located.

The vocational movement in education, moreover, has exerted a wide influence in all education. There is everywhere among thinking people an admission that future mogres. in education will be in the development of applied arts and sciences, and that the only twuly cultural education is that which has its roots in the problems of actual life.

But this is no time for self-complacency on the part of land grant institutions. Their establishment was a long step forward in universal, useful education, but it did not remedy all the defects of the existing educational system. The free public high schools which came to fill the gap betwen the elementary schools and tho miversities have in many cases fallen victim to false ideas of crilture and must radically change their curricula if they are to become servants of modern life. Moreover, they have been located in towns and cities and made no adequate provision for educating the youth of rural communities. Efforts more or less successful have been made to bring secondary education to rural young people within the bounds of their orn communities by means of the township and rural high schools, and the consolidated 
schools. These schools for the most part, however, have traversed the usual fields of general education.

The multiplicity of inventions and the rapid and enormous increase in the application of science to manufacture removed industries from the home and brought about the development of the modern industrial system. The educational system, with the exception of a few sporadic experiments, continued to release from the school room a steady stream of immature youth, unprepared for the conditions of the industrial world which immediately receives them. Educators either remained blind to this fact, or, fearing dangerous innovations, remained silent. Institutes of technology were founded with private funds and industrial organizations formulated courses of training for their workers within their own walls. These means gave only a limited relief, however, from a condition which was universal in its existence and therefore could be reached adequately only through universal means.

In answer to the urgent, widespread need, the SmithHughes Act was passed, providing for vocational education below college rank and carrying with it immense possibilities. The conditions of war under which it was brought to adoption, the widespread and recognized need which it attempts to fill, its possibilities for good and evil, are a remarkable reminder of that other epoch-making act in 1862 . It has brought rejoicing to those who see in it a just and fair provision for fitting the child to adjust himself successfully to the economic world. Yet that the Act carries within it an element of danger has been pointed out. That danger is that in our zeal to enable a blacksmith to become an efficient blacksmith, and a farmer a proficient farmer, we may inadvertently sow the seeds of class distinction. From the beginning of our national existence our wills have been resolutely set against the division of society into upper and lower classes. Our educational system, numerous as have been its defects, has nevertheless served admirably in bringing about an unexampled democratization of society. That several of the most distinguished executives of the nation have come from the lowly log cabin has been a matter of great national pride with us as symbolizing the reality and truth of our democracy.

The task of applying the provisions of the SmithHughes Act, like that of the great Land Giant Act, will require foresight and wisdom, careful experimenting and study. We must not foster the thought that the son of the blacksmith must inevitably be a blacksmith. nor that 
the son of a farmer must necessarily stay on the land. As a matter of fact, the interchange of blood between country and city has been one of the most wholesome, leavening influences upon our national life. We must encourage a continuance of this interchange, rather than discourage it. We must offer to every child, whether of urban or rural community, opportunity to enter whatever vocation or profession he may choose.

What is needed is a balance between vocational or industrial education on the one hand and liberal education on the other, a type of education which shall give a broad insight into the industrial world of activity and yet develop the indiridual's capacity for esthetic appreciation to the highest degree of which he is capable. The purpose underlying the training of the child industrially must not alone be the production of more at less cost. Industrial training in education is not to be allied with exploitation. The chief, animating purpose must be to insure the welfare of the child by widening his opportunities. It is only thus that we may safeguard the velfare of society.

The new education must embody in it the larger, broader aim of training for citizenship. In the past we have believed that training in the principles of citizenship would somehow take care of itself. We have believod that no group or nationality could withstand the fusing influence of our great melting pot. How greaty we have erred in this belief is evidenced most strongly by the persistence of German ideals among German immigrants and their descendants. We have failed to make of many of these people real Americans. The existence of conflicting groups in our national life is shown by the continuous struggle between labor and capital. The drvision of a large portion of our population into two great groups is not without elements of good, within certain limits. Both labor and capital, have learned the value and power of united force, of co-operation, in contrast to individual competition. But the elements of danger to the Republic in the situation are immense. Should the schism prove permanent, then we are already divided into classes. But it must not continue. The first consideration of all American citizens must be, not the interests of the laboring group, nor the interests of the moneyed group, but the interests of free America. Through the schools as the first medium we must teach that American citizenship with its gift of privileges, imposes duties. We must instill into the minds of growing boys and girls ideals of citizenship which shall insure justice to all. With 
justice secured, the forces of labor and capital will be free to unite to insure a more perfect democracy.

The evolution of the new education in which industry is to be safely utilized at its full value, and in which the spirit of American citizenship is to be instilled into the child, forms one of the great tasks of the readjustment period and the future. The land grant institutions of the United States embody the successful working out of the first attempt of the federal gorernment to connect the industries with education. Once pioneers in a new field, braving adversities to be encountered in untrodden paths, now accepted as duly accredited members of the society of higher educational institutions, they must not forget their obligations to those who would blaze new trails. They cannot ignore new educational needs.

There are two functions which the Agricultural and Mechanic Arts colleges may be expected to perform in helping to initiate universal secondary vocational education. The first of these is to make available in adapted form to secondary schools, for use in their curricula, a considerable part of the practical subject matter in agriculture, home economics, and mechanic arts which has heretofore been reserved for the college curricula. The second of these functions is that of providing trained men and women for the teaching corps of secondary vocational schools.

The war has demonstrated as never before the value of education, especially of the kind of education which prepares men and women for definite tasks. During the war the government manifested its appreciation of the technically trained man by using the colleges and universities in the training of national army men and in the establishment of the Students' Army Training Corps. It indicated its recognition of the need which the educational institution must fill in the reconstruction period, by its system of utilizing college equipment and teaching force in preparing men for military service. It thereby made it possible for practically all to retain their full instructional forces and remain prepared to handle problems as they might arise during the conflict and thereafter.

In the development of the educational system of this country, the national government has come to participate to a large extent in educational affairs. National establishment and supervision of schools for the Indians, for the territory of Alaska, and for our island possessions were necessary. The first direct entrance of the national government upon educational relations of a prac- 
tical character and on an extensive scale, was the establishment of the land grant colleges of agriculture and mechanic arts. This has been followed recently by provision for vocational education in the high schools. Our disabled soldiers and sailors require special training for rehabilitation and this the government is providing. These different educational activities of the national government are not administered by a single government agency. On the contrary, as a natural outgrowth of our rapid development, national educational supervision is scattered through eight of the ten departments of the federal government.

There is now a movement under way in this country to establish a federal department of education and to centralize all of the educational activities of the national government under one head. From the theoretical standpoint, this would seem logical and in line with efficiency. The established system, however, possesses advantages which cannot be orerlooked and which would be seriously jeopardized by a strong centralization of supervision. When the Land Grant colleges were established, their national supervision was entrusted for the most part to the Department of Agriculture. For more than fifty years these institutions have worked together and out of this experience has grown a most satisfactory and harmonious relationship. The common interests, aims, and ideals of the agricultural colleges and the Department of Agriculture have made possible more rapid progress than could otherwise have been achieved. Were a strongly centralized fereral department of education to be established. the old, conservative, academic ideals of education might easily predominate and retard immeasurably the evolution of the new education in which industry is to be properly utilized and the best Americanism developed.

There are undoubtedly improvements needed in our national education which could be best effected through a strong national educational center, and the project is one which merits the best thought of all those interested in the cause of education. But in working out a plan for centralization, the advantages of the present system must be safeguarded if all educational forces are to maintain a united front.

The program which I have outlined is a program for education in the United States, a program designed to promote the best Americanism, the purest ideals of democracy. But education in this country alone is insufficient. With modern transportation facilities, with modern methods of gathering and transmitting news, with 
modern interests transcending community, state, and national lines, practically any national problem may at any moment become an international problem. Education cannot deal with the United States as it was a century ago, when our educational system was developing-a nation isolated, self-supporting, self-sufficient.

Ultimately, the education which is necessary is world education. Every step possible must be taken to insure that education be disseminated over the entire world and that it be democratic education, not education designed to develop efficiency at the expense of initiative, or acquisitiveness at the expense of justice. Moreover, peoples of varying temperament, ideals, and other racial characteristics must by education be led to an understanding of each other. Insistence on these two principles in world education-democracy and mutual understanding -will do more than any other one thing to make wars impossible. Any league of nations which is established may wisely have somewhere in its organization, a commission on education to suggest to the constituent nations large general plans which would lead toward the fulfillment of the ideals which all right-thinking nations seek. We cannot have a world curriculum, but we can have world ideals toward which education in all countries may strive.

Upon us, servants of the new era in world politics and in world education, has the mantle of the ancient leaders fallen. They laid the foundation upon which we must build the super-structure. By the touch of that mantle in our hands-be they quickened with justice and zeal-the waters of error, of injustice, of prejudice, will be swept aside, and education for democracy will cross over into its own. 
The Reverend Wilbur Nesbit Mason, Bachelor of Arts, Master of Arts, Bachelor of Sacred Theology, Doctor of Divinity, Member and Acting Secretary of the Board of Administration, brought felicitations from that body, speaking as follows:

ADDRESS GY DOCTOR MASON

Mr. President, Distinguished Visitors, Faculty, and Friends:

It is reason for real regret on your part, at it certainly is cause of regret to me, that his Excellency, Governor Allen, Chairman of the Board of Administration, finds it impossible to be present to bring the greetings of the State and of the Board at this time. The Governor has already sent his regrets; but yesterday asked me to express his high personal esteem for President Jardine and his conficient anticipation of an administration that will bring to this College enlarging usefulness in the service of the State.

The inauguration of a new president is an important event in the history of any institution. This is especially true in the history of the Agricultural College. Coming as you do, President Jardine, as successor to our honored friend, Dr. Henry J. Waters, and becoming the most recent addition to the line of honorable men who have been President of this institution, you are charged with a large task in carrying forward the work in these stirring and momentous days. Were you only to maintain the high standard of service rendered by your prederessors, you would have a man's task; but to do what their work has made possible and what your own high sense of duty and privilege demands, you must more than maintain what has already been wrought. The past history of this institution and the present opportunity challenge you to render the best service ever performed by any President of this College. I congratulate you upon the high resolve that we know has formed within you, and with eager confidence we pledge to you our support in seeking the goal that you have set before you.

I congratulate you upon the material with which you have to work. Some men take the rude stone and with the touch of gerius shape it into the stately building, eloquent of high thought, soaring into the very presence of the Divine. Another man may form rough marble into a statue whose brast scems truly to heave with the throbbing life of a Venus de Milo. The painter mixes his colors and with the brush of a master, creates a Sistine Madonna whose parting lips speak of the Mother- 
hood of God. But you deal with material far more sacred and crowded with far greater possibilities. Here are gathered the raw materials out of which are made, under your guidance, men and women of tomorrow. Kindled by your enthusiasm, inspired by your ideals, they are to make the citizenry of a progressive commonwealth; men who will right wrong, correct abuses and lift the standards of living until, with the poet, we cry out, "What a work of God is a man!"

I congratulate you upon the motives to which you are privileged to appeal. In the midst of a world so given to material things and so absorbed in measuring values in terms of sense, the College, and especially the President who directs the policy of the College, have a large and definite task set before them that they may keep alive and fan into a glowing flame those passions of youth that are the finest things of human life. If hate is ever justified in the heart of men, shall it not be a hatred of wrong and of falsehood? What love, among all our human loves, may be compared with the love for truth? If ever the hand grows weary at its work or the heart grows faint before its task, the educator must arouse that courage and devotion which will hold the young steady in their loyalty to truth. "Not what I am, but what I aspired to be, comforts me." It is the educator who opens to the inquiring mind that undiscovered country of high aspirations and holy enthusiasms. What matter the odds against a man who has within himself these wellsprings of eternal life? To tap these springs, Mr. President, is your great privilege.

I congratulate you because of the mission to which you are to point the young people who are under your care. Education may almost be said to be another name for vision. The "mute inglorious AIilton" or a "Cromwell guiltless of his country's blood" is such. not merely because he has had no chance, but because he has not climbed to the mount of vision whence he may see the widesnread fields of opportunity. It is the business of the College to guide young people to these peaks of vision. and you, Mr. President, may truly be called the chief guide of this group of guides that we call the faculty. Mien are willing, even glad, to do if only they may find the thing that is worth doing. You are to aid them in making the discovery. You are to tell them that not more acres in their farms, more grain in their bins, more cattle on our kansas plains, are to be the goal of their striving; but a finer tone in community life, a kindlier spirit and truer, vider brotherhood-these are the things really worth while. 
The honored guest representing the United States Government here today, Commandant at Funston, General Leonard Wood, has more than once given living proof of the point I make. Years ago, when home from his great work in cleaning up the Island of Cuba, making it a fit place in which to live, Harvard University, of which he was twice an alumnus, conferred upon him the highest honorary distinction she could give-the Doctorate of Laws. President Eliot, in granting the degree, rightly called him,-remembering his remarkable work in Cuba- "Redeemer of a Province." On the same visit home, as I recall, a great corporation offered him its presidency with a salary of $\$ 30,000$ per year. General Wood, in declining it, said. "Gentlemen, there are some things money cannot buy." From his standpoint, far better was it to stamp out yellow fever in Havana, making the conditions of human life not only tolerable but joyous. So are you, Mr. President, to teach our Kansas youth that fine idealism which will make them redeemers of a commonwealth; to redeem farm life from its dreary monotony and its crass materialism, to make the farmer's home a place of beauty, to give the village such a quickening that it shall break away from its narrow and killing provincialism, to make the city wholesome and to make the slum impossible - this is a work worth while.

In the name of the State and of the Board having charge of this College, I summon you, Mr. President, to this far-reaching service.

The Music Faculty Quartet then sang "Loch Lomond," as arranged by Clough Leighter.

\section{ADDRESS BY GENERAL, WOOD}

Major General Leonard Wood, United States Army, Doctor of Medicine, Doctor of Laws, Commanding Officer, Camp Funston, was then introduced, and expressed his appreciation of the spirit of cooperation and helpfulness shown by President Jardine and the Faculty in establishing educational facilities for the soldiers on the campus and at Camp Funston. He touched upon the subject of universal obligation for service to the Nation. He emphasized the value of prohibition in training the army, pointing out the fine qualities kept fresh by abstinence from intoxicants. He spoke in praise of the men in the Thirty-fifth, Eighty-ninth, and Tenth Divisions. 
Frank Strong, Bachelor of Arts, Master of Arts, Doctor of Philosophy, Doctor of Laws, Chancellor of the University of Kansas, brought felicitations from the other educational institutions established by the State of Kansas. He said:

\section{ADDRESS BY CHANCELLOR STRONG}

\section{Mr. Chairman, Mr. President, and Ladies and Gentlemen:}

I wish to express my great pleasure in being allowed to represent the University of Kansas at the inauguration of President Jardine. On behalf of the University of Kansas I congratulate him most sincerely and hope for him a long and successful administration. I do this both as the head of a sister institution and a citizen of the State and as an alumnus of the Kansas State Agricultural College, for the College did me the honor of granting me an honorary degree when President Henry J. Waters was inaugurated.

I feel a sincere interest in the work of the Agricultural College. The day is past when State institutions look with envy and distrust upon each other. The more this great College thrives and adds to the wealth and happiness of the State the better it is for all the rest of us. So far as the University of Kansas is concerned, the larger support you get at Manhattan, the better we shall like it.

Of course the great field of this College relates to the greatest of all the industries of this State. Kansas is in very large measure still an agricultural community. It is no wonder that it regards with so much concern and confidence the development of its Agricultural College. I believe the state is happy also in the fact that the Agricultural College does not confine itself to the immediate economic advantages of the state, but also trains its young people for a high and noble position in life and for high ideals of conduct and citizenship.

A good deal has been said here and elsewhere in regard to the current from the farm to the town and city, and the relation of agricultural colleges to it. In my opinion, this current cannot be stopped. It has been running for many centuries. There ought to be a compensating current running from town to the country. This is not likely to happen, however, until conditions of living in the country, until Church, school and social opportunities are on the whole commensurate with those of the town and city. To accomplish this, roads that are 
good the year round are necessary, large, well-built, and well-appointed schools are indispensable, well-supported churches with competent leadership are also indispensable, and with these must go some social center at which the social life of the community may be adequately cared for.

Dr. Frederick W. Lewis, President of the College of Emporia, who had expected to present the greetings of the privately supported institutions of Kansas, was unable to be present.

Samuel Alexander Lough, Bachelor of Arts, Master of Arts, Doctor of Philosophy, President of Baker University, was introduced, and spoke as follows:

\section{ADDRESS BY DOC'IOR LOUGH}

\section{Mr. Chairman, Mr. President, Ladies and Gentlemen:}

I sincerely and heartily join this audience in the feeling of regret that President Lewis is not present. Since he is not here it is with great pleasure that I bring the congratulations of the private colleges of the State to President Jardine and the great institution over which he has been called to preside. The State of Kansas is to be congratulated upon securing as the President of one of her greatest educational institutions this man, who has been so farorably identified with the college and now comes to his great task with ripe scholarship, extensive experience, and demonstrated fitness.

We of the private colleges gladly participate with all the citizens of Kansas in legitimate pride in the history and development of this College. We rejoice as we think of the fine way in which our Kansas Agricultural College has successfully met the challenge of this great agricultural State. This College has had a great past; in its present activities it is effectively and extensively serving the interests of the State; it fronts a future of opportunity and possibility even greater than the achievement of the past and the service of the present. Two conditions sound educational effort must meet: It must provide vocational training in harmony with the industrial and economic conditions; it must equip boys and girls so trained to give delightful content to the leisure part of life. The vocational challenge of this state is and will always be prevailingly agricultural. We now everywhere recognize that one of the big and perplexing problems 
of rural life is spiritual and social in nature. Consequently there exists nowhere a greater educational opportunity than that which confronts this institution. With all thoughtful citizens of this Commonwealth we here express our satisfaction with our Board of Administration in selecting President Jardine to direct the activities of this College in this great work.

The private colleges do not covet this magnificent plant. They do not envy you because of your great opportunity. They heartily congratulate you. Speaking for all, let me assure you that you have and will always have our hearty sympathy, our sincere good will, and our loyal support. We sincerely wish for this institution a more stable and increasingly abundant support. To this end you may confidently count on us to vote and work.

The Benediction was then pronounced by the Reverend Doctor Fisher.

At 6 o'clock the annual Farm and Home Week dinner was served in the barracks by the Department of Domestic Science. The dinner was this year in special honor of President and Mrs. Jardine.

President Jardine spoke briefly, introducing Mr. Francis D. Farrell, Dean of Agriculture, as Toastmaster. Addresses were made by Professor S. A. Beach, Iowa State College; Captain D. D. Casement of Manhattan; Mr. George I. Christie, Assistant United States Secretary of Agriculture; Doctor D. E. Kurtz, President of McPherson College; Doctor Wilbur N. Mason and Mr. C. W. Green, of the Board of Administration; Doctor Julius T. Willard, Vice-President of the College and Dean of General Science; Mr. A. A. Potter, Dean of Engineering; and Mr. Harry Umberger, Acting Dean of College Extension. Mrs. Jardine responded to a toast offered in her honor.

The ceremonies of Inauguration Day were concluded with an informal reception in Nichols Gymnasium, complimentary to President and Mrs. Jardine. 


\section{BIOGRAPHICAL}

Doctor William Marion Jardine comes from a family of farmers. His parents were engaged in farming in Oneida County, Idaho, in 1879, when he was born.

Brought up on farms and ranches, Doctor Jardine acquired a practical knowledge of agriculture before attending college. He still owns a farm and directs its operation.

Doctor Jardine was graduated from the Utah Agricultural College in 1904, and immediately became Instructor in Agronomy in that institution. In the following year he became Professor of Agronomy, resigning that position to take charge of dry land investigations for the United States Department of Agriculture. In 1910 he came to the Kansas State Agricultural College as Professor of Agronomy, and three years later became Dean of Agriculture and Director of the Agricultural Experiment Station.

In 1912 Doctor Jardine was lecturer in the Graduate School of Agriculture, which was held that year at the Michigan Agricultural College. From 1908 to 1915 he was a director of the Northern Pure Seed Company. He is a fellow of the American Association for the Advancement of Science. In 1915-1916 he was President of the International Dry Farming Congress, and in the following year he was elected President of the American Society of Agronomy. He was Vice-Chairman of the Kansas Council of Defense and Chairman of its Committee on Agricultural Production. In 1916 Campbell College conferred upon him the degree of Doctor of Laws.

Doctor Jardine was married to Miss Effie Nebeker in 1905. They have three children.

Doctor Jardine is recognized as one of the world's principal authorities on dry farming, and his papers and bulletins on this subject are read in foreign countries as well as in the United States. 


\section{HISTORICAL}

The Kansas State Agricultural College was founded in 1863.

Preceding Doctor Jardine, six Presidents served the College, as follows:

1863-1873-The Reverend Joseph Denison, A. M., D. D.

1873-1878-The Reverend John A. Anderson, A. B.

1878-1897-The Reverend George Thompson Fairchild, A. M., LL. D.

1897-1899-Thomas Elmer Will, A. M.

1899-1909-Ernest R. Nichols, A. M., Ph. D.

1909-1918-Henry Jackson Waters, B. S. A., LL. D.

\section{ARRANGEMENTS FOR THE INAUGURATION}

Arrangements for the inauguration of Doctor Jardine were in charge of a general committee consisting of Professor Albert Dickens, '93; Professor Harry Llewellyn Kent, '13; and Doctor Julius Terrass Willard, '83.

Special committees charged with particular duties were as follows:

Committee on Ceremonies-Professor J. E. Kammeyer, Professor J. V. Cortelyou, and Dean Helen Bishop Thompson.

Committee on Music-Professor A. E. Westbrook and Professor R. H. Brown.

Committee on Military Affairs-Captain George Sturges and Professor R. H. Brown.

Committee on Luncheon-Miss Margaret Haggart, Professor J. O. Hamilton, Miss Jen L. Cox, and Miss Helen Green.

Committee on Evening Reception-Dean Mary Pierce Van Zile, Miss Frances Brown, and Dean Harry Umberger.

Committee on Decorations_-Professor M. F. Ahearn, Mrs. Bessie Birdsall, and Miss Araminta Holman.

Committee on Engraving and Printing-Professor Nelson Antrim Crawford. 


LIBRARY OF CONGRESS

||||||||||| ||| || ||| ||||||||||||||||||||||

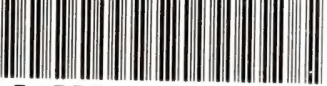

0 0027751283 